\title{
Stimulation of Platelet Death by Vancomycin
}

\author{
Syeda T. Towhid ${ }^{a}$ Eva-Maria Schmidt ${ }^{a}$ Alexander Tolios ${ }^{a, c}$ Patrick Münzer ${ }^{a}$ Evi Schmid ${ }^{a}$ \\ Oliver Borsta,c Meinrad Gawaz ${ }^{c}$ Evi Stegmann ${ }^{b, d}$ Florian Lang ${ }^{a, d}$ \\ aDepartment of Physiology, University of Tübingen; 'bepartment of Microbial Genetics, University \\ of Tübingen, Tübingen; 'Department of Cardiology and Cardiovascular Medicine, University Hospital \\ Tübingen, Tübingen; dcontributed equally and thus share last authorship
}

\author{
Key Words \\ Platelets $\bullet$ Phosphatidylserine $\cdot$ Caspase- $3 \cdot$ Apoptosis $\bullet$ Cell membrane scrambling $\bullet$ Mitochondrial \\ potential $\cdot \mathrm{Ca}^{2+}$
}

\begin{abstract}
Background/Aims: Side effects of vancomycin, a widely used antibiotic, include thrombocytopenia. The vancomycin-induced thrombocytopenia has been attributed to immune reactions. At least in theory, thrombocytopenia could result in part from the triggering of apoptosis, which results in cell shrinkage and cell membrane scrambling with subsequent phosphatidylserine exposure at the cell surface. The cell membrane scrambling could be initiated by a signaling involving increase of cytosolic $\mathrm{Ca}^{2+}$ activity, ceramide formation, mitochondrial depolarization and/or caspase activation. Vancomycin has indeed been shown to trigger neutrophil apoptosis. An effect of vancomycin on platelet apoptosis has, however, never been tested. The present study thus explored the effect of vancomycin on platelet activation and apoptosis. Methods: Human blood platelets were exposed to vancomycin and forward scatter was utilized to estimate cell volume, annexin V-binding to quantify phosphatidylserine (PS) exposure, Fluo-3 AM fluorescence to estimate cytosolic $\mathrm{Ca}^{2+}$ activity $\left(\left[\mathrm{Ca}^{2+}\right]_{i}\right)$, antibodies to quantify ceramide formation and immunofluorescence to quantify protein abundance of active caspase-3. Results: A 30 minutes exposure to vancomycin $(\geq 1 \mu \mathrm{g} /$ $\mathrm{ml}$ ) decreased cell volume, triggered annexin V-binding, increased $\left[\mathrm{Ca}^{2+}\right]_{\mathrm{i}}$, activated caspase 3 , stimulated ceramide formation, triggered release of thromboxane $B_{2^{\prime}}$ and upregulated surface expression of CD62P (P-selectin) as well as activated integrin $\alpha_{\| 1} \beta_{3}$. Annexin V-binding and upregulation of CD62P (P-selectin) and integrin $\alpha_{\| b} \beta_{3}$ was significantly blunted by removal of extracellular $\mathrm{Ca}^{2+}$. Annexin $\mathrm{V}$-binding was not significantly blunted by pan-caspase inhibitor zVADFMK $(1 \mu \mathrm{M})$. In conclusion, vancomycin results in platelet activation and suicidal platelet death with increase of $\left[\mathrm{Ca}^{2+}\right]_{i}$, caspase-3 activation, cell membrane scrambling and cell shrinkage. Activation and cell membrane scrambling required the presence of $\mathrm{Ca}^{2+}$, but not activation of caspases. Conclusion: Vancomycin exposure leads to platelet activation and apoptosis.
\end{abstract}




\section{Introduction}

Vancomycin is widely used in the treatment of infections with Gram-positive pathogens [1]. Side effects of vancomycin include thrombocytopenia [2-4], which has been attributed to an immune reaction [5-8]. Alternatively, thrombocytopenia could result from excessive suicidal platelet death or apoptosis [9]. As a matter of fact, vancomycin has been reported to trigger apoptosis of neutrophil granulocytes [10]. To the best of our knowledge, an effect of vancomycin on platelet apoptosis has never been reported.

The present study explored the effect of vancomycin on platelets. Platelet apoptosis is apparent from cell membrane scrambling [11-13]. Mechanisms involved in the triggering of platelet apoptosis include increase of cytosolic $\mathrm{Ca}^{2+}$ activity [14], ceramide formation [12], and caspase-3 activation [11-13]. Platelet activation is followed by stimulation of exocytosis leading to CD62P selectin and activated integrin $\alpha_{\mathrm{IIb}} \beta_{3}$ expression at the platelet surface [15, 16]. Moreover, following platelet activation integrin $\alpha_{\mathrm{IIb}} \beta_{3}$ changes its conformation into a high-affinity state $[17,18]$.

Platelet activation and apoptosis are two simultaneous and inter-dependent mechanisms [19]. Platelet apoptosis may result in thrombocytopenia, platelet activation in thrombosis.

The present observations indeed revealed that exposure of platelets to vancomycin triggers cell shrinkage, cell membrane scrambling and increase of CD62P (P-selectin) as well as activated integrin $\alpha_{11 b} \beta_{3}$ (CD41/61) abundance at the platelet surface. The cell membrane scrambling was paralleled by caspase- 3 activation, but was not abrogated by pan-caspase inhibitor zVAD-FMK (Z-Val-Ala-Asp-fluoromethyl ketone). Vancomycin increased cytosolic $\mathrm{Ca}^{2+}$ activity and stimulated ceramide formation. Removal of $\mathrm{Ca}^{2+}$ virtually abolished vancomycin induced cell membrane scrambling and CD62P (P-selectin) as well as activated integrin $\alpha_{11 b} \beta_{3}$ abundance.

\section{Materials and Methods}

\section{Isolation and stimulation of human platelets}

Fresh ACD-anticoagulated blood was obtained from healthy volunteers between the age of 22 to 50 years with informed consent according to the Ethics Committee of the Eberhard Karl University Tübingen, Germany (184/2003V). The blood was centrifuged at $200 \mathrm{~g}$ for 20 minutes at $25^{\circ} \mathrm{C}$. The platelet rich plasma was separated, Tyrode buffer added $\left(137 \mathrm{mM} \mathrm{NaCl}, 2.8 \mathrm{mM} \mathrm{KCl}, 12 \mathrm{mM} \mathrm{NaHCO}_{3}, 5 \mathrm{mM}\right.$ glucose, $0.4 \mathrm{mM}$ $\mathrm{Na}_{2} \mathrm{HPO}_{4}, 10 \mathrm{mM}$ HEPES, $0.1 \% \mathrm{BSA}, \mathrm{pH} 6.5$ ) in a 1:6 volumetric ratio and centrifuged at $900 \mathrm{~g}$ and $25^{\circ} \mathrm{C}$ for 10 minutes. The platelet pellet was resuspended in $250 \mu$ l of Tyrode buffer ( $\mathrm{pH} 7.0$ ). Care was taken not to expose platelets to excess mechanical stress or oxygen.

$10^{6}$ platelets were stimulated in a total volume of $1 \mathrm{ml}$ Tyrode buffer $\left(\mathrm{pH} 7.4\right.$ with $2 \mathrm{mM} \mathrm{CaCl}_{2}$ ). Where indicated, vancomycin (synthesized by the Department of Microbiology and Biotechnology, Eberhard Karl University Tübingen) was added at the indicated concentrations $(1,5,10$ and $15 \mu \mathrm{g} / \mathrm{ml})$ for 30 minutes at $37^{\circ} \mathrm{C}$. A negative control without vancomycin and a positive control with ionomycin $(1 \mu \mathrm{M})$ was analyzed simultaneously with each set of experiment. Since ionomycin was dissolved in DMSO, a solvent control was measured in addition.

\section{LDH release}

To determine the vancomycin-induced LDH release platelets were centrifuged and LDH concentration in the supernatant determined by ELISA (Promega, CA, USA).

Phosphatidylserine (PS) exposure

Phosphatidylserine exposure was measured following stimulation with vancomycin, centrifuging the cells at $1000 \mathrm{~g}$ for 2 minutes followed by washing once in Tyrode buffer ( $\mathrm{pH} 7.4$ ) with $2 \mathrm{mM} \mathrm{CaCl}_{2}, \mathrm{Annexin}$ V-Fluos (1:20 dilution, Immunotools, Germany) staining in the same buffer and incubating at $37^{\circ} \mathrm{C}$ for 30 minutes. The fluorescence was measured in FL-1 of a BD FacsCalibur (BD Biosciences, CA, USA). 
Calcium measurements

Intracellular $\mathrm{Ca}^{2+}$ concentration was measured following stimulation with vancomycin as indicated, washing once in Tyrode buffer ( $\mathrm{pH} 7.4$ ) with $2 \mathrm{mM} \mathrm{CaCl}_{2}$ and staining with $5 \mu$ M Fluo-3AM (Biotinium, USA) in the same buffer and incubating at $37^{\circ} \mathrm{C}$ for 30 minutes. The fluorescence was measured in FL-1 of a BD FacsCalibur (BD Biosciences, CA, USA).

\section{Mitochondrial membrane potential}

Platelets were first stimulated with vancomycin as described before and $10^{7}$ platelets were suspended in phosphate buffered saline (PBS) (Invitrogen, CA, USA) supplemented with $1 \mathrm{mM} \mathrm{MgCl}, 5.6 \mathrm{mM}$ glucose, $0.1 \% \mathrm{BSA}$ and $10 \mathrm{mM}$ HEPES (pH 7.4) in a total volume of $1 \mathrm{ml}$ and stained with $10 \mathrm{nM} \mathrm{DiOC}_{6}$ (Invitrogen, CA, USA) for 10 minutes. The stained cells were centrifuged at $1000 \mathrm{~g}$ for 5 minutes at $20^{\circ} \mathrm{C}$, resuspended in PBS and measured in FL-1 [11].

Caspase-3 activity

Active caspase- 3 produced in the cells was measured by CaspGlow Fluorescein Active Caspase-3 Staining kit from BioVision (CA, USA) as per the manufacturer's instruction. Fluorescence was measured in FL-1 in BD FACS Calibur (BD Biosciences, CA, USA). Two sets of experiments were done to determine caspase-3 activity. One set contained Tyrode buffer ( $\mathrm{pH} 7.4$ ) with $2 \mathrm{mM} \mathrm{CaCl}_{2}$, the second set contained Tyrode buffer (pH 7.4) with $0.5 \mathrm{mM}$ EGTA. In each set of experiments $10^{6}$ platelets $/ \mathrm{ml}$ Tyrode buffer $(\mathrm{pH} 7.4$ with $2 \mathrm{mM} \mathrm{CaCl}$ ) were stimulated for 30 minutes at $37^{\circ} \mathrm{C}$ with vancomycin $(1-15 \mu \mathrm{g} / \mathrm{ml})$, washed once in Tyrode buffer ( $\mathrm{pH}$ 7.4) and stained with CaspGlow Fluorescein Active Caspase-3 according to manufacturer's instructions.

\section{Immunofluorescence}

Fresh isolated platelets were adhered to a fibrinogen surface $(20 \mu \mathrm{g} / \mathrm{ml})$ on chamber slides, stimulated as described before and fixed with $2 \%$ paraformaldehyde for 2 hours at $37^{\circ} \mathrm{C}$. Then paraformaldehyde was removed and the platelets were washed with PBS by centrifuging at $1000 \mathrm{~g}$ for 2 minutes at $25^{\circ} \mathrm{C}$ and blocked with $2 \%$ bovine serum albumin for 30 minutes, followed by a triton X-100 (0.1\% in PBS) treatment for permeabilization. Then the platelet-coated slides were stained with Annexin V-Fluos (1:100 dilution, Roche, Mannheim, Germany) or 1:50 dilution of caspase-3 rabbit monoclonal antibody (Cell Signaling Technology) by incubating for 2 hours at room temperature. Chamber slides were washed and incubated with secondary antibody labeled with FITC (Santa Cruz, USA) in the case of caspase-3 staining. The actin cytoskeleton was stained with rhodamine-phalloidin (Invitrogen). Confocal microscopy was performed using a Zeiss LSM5 EXCITER Confocal Laser Scanning Microscope (Carl Zeiss Micro Imaging, Jena, Germany) with a A-Plan 63x ocular. Colocalization of annexin $\mathrm{V}$ with actin cytoskeleton was analysed in order to define the location of annexin $\mathrm{V}$ binding on the cell.

\section{Ceramide formation}

For detection of ceramide formation, $10^{8}$ platelets $/ \mathrm{ml}$ were stimulated for 60 minutes as described before and centrifuged at $2000 \mathrm{~g}$ for 2 minutes and the pellet was incubated with $50 \mu \mathrm{l}$ of mice antibody to human ceramide (1:5 dilution, Alexis, USA) in PBS with $1 \%$ BSA for 1 hour at $37^{\circ} \mathrm{C}$ and $5 \% \mathrm{CO}_{2}$. Then primary stained cells were centrifuged at $1000 \mathrm{~g}$ for 2 minutes and the pellet was stained with $50 \mu \mathrm{l}$ of secondary goat anti-mouse IgG (1:50 dilution, BD Pharmingen, Hamburg, Germany) for 20 minutes. The reaction was stopped with $200 \mu \mathrm{PBS}$ and measured immediately in FACS analysis. The mean fluorescence of the FITC-labeled secondary Ig was measured.

Expression of activated integrin $\alpha_{I I} \beta_{3}$ and CD62P (P-selectin)

$10^{6}$ platelets/ml were suspended in Tyrode buffer ( $\left.\mathrm{pH} 7.4\right)$ with $2 \mathrm{mM} \mathrm{CaCl}_{2}$ or in Tyrode buffer $(\mathrm{pH}$ 7.4) with $0.5 \mathrm{mM}$ EGTA and stimulated with vancomycin or $1 \mu \mathrm{M}$ ionomycin for 30 minutes at $37^{\circ} \mathrm{C}$, stained with 1:10 dilution of PAC-1 FITC antibody targeted against the active conformation of integrin $\alpha_{\mathrm{IIb}} \beta_{3}$ and anti-CD62P FITC (both from BD Pharmingen, USA) for $30 \mathrm{~min}$ at $37^{\circ} \mathrm{C}$, washed once and analyzed in FACS. 
Detection of Thromboxane $B_{2}\left(T x B_{2}\right)$ with ELISA

The vancomycin-treated platelets were centrifuged at $1000 \mathrm{~g}$ for 2 minutes at $25^{\circ} \mathrm{C}$ and $1000 \mu \mathrm{l}$ of the supernatant was mixed with $200 \mu \mathrm{l}$ methanol (Merck, Germany) and vortexed briefly. $50 \mu \mathrm{l}$ of the sample was added to each of the wells of the coated (Thromboxane $B_{2}$ ) ELISA plates (Oxford Biosciences, UK) and incubated at room temperature with shaking for 2 hours. The plate was washed three times with 300 $\mu \mathrm{l}$ washing buffer (1:10 dilution in PBS) (Thromboxane $B_{2}$ ELISA kit, Oxford Biosciences) and incubated 1 hour with $50 \mu \mathrm{l}$ HRP-conjugated $\mathrm{TxB}_{2}$ antibody. After washing again three times with 1:10 dilution of the washing buffer, incubation for 30 minutes with $150 \mu \mathrm{l}$ of TMB substrate (Thromboxane $\mathrm{B}_{2}$ ELISA kit, Oxford Biosciences) and blocking with $1 \mathrm{~N} \mathrm{HCl}$, measurements were done immediately at $450 \mathrm{~nm}$ in a Biotek Power Wave XS2 ELISA reader against a standard of 0, 0.1, 0.2, 0.4, 1, 2, 4 and $10 \mathrm{ng} / \mathrm{ml}$ thromboxane $\mathrm{B}_{2}$ (thromboxane $\mathrm{B}_{2}$ ELISA kit, Oxford Biosciences). The amount of $\mathrm{TxB}_{2}$ formed in the samples was determined from a curve of concentration vs actual absorbance with Microsoft Excel 2007. The experiment was repeated with Tyrode buffer $(\mathrm{pH} 7.4)$ containing 0.5 mM EGTA to determine the role of extracellular calcium on thromboxane metabolism.

Effect of caspase on phosphatidylserine exposure

$10^{6}$ platelets were suspended in a total volume of $1 \mathrm{ml}$ Tyrode buffer ( $\mathrm{pH}$ 7.4) in either the presence of $2 \mathrm{mM}$ extracellular $\mathrm{CaCl}_{2}$ or in the presence of extracellular calcium chelator $0.5 \mathrm{mM}$ EGTA (Carl Roth, Germany). Platelets were incubated for 30 minutes at $37^{\circ} \mathrm{C}$, centrifuged and washed with Tyrode buffer $(\mathrm{pH} 7.4)$ at $1000 \mathrm{~g}, 25^{\circ} \mathrm{C}$ for 2 minutes and resuspended in $1 \mathrm{ml}$ of the same buffer, stimulated with 10 and $15 \mu \mathrm{g} / \mathrm{ml}$ concentration of vancomycin at $37^{\circ} \mathrm{C}$ for 30 minutes, washed once in Tyrode buffer $(\mathrm{pH} 7.4)$ and stained with Annexin V-Fluos (1:20 dilution, Immunotools, Germany) in Tyrode buffer (pH 7.4) $2 \mathrm{mM} \mathrm{CaCl}_{2}$ for 30 minutes at $37^{\circ} \mathrm{C}$. Immediate measurement of fluoresence was done in FL-1 with FACS Calibur. To define the role of caspase on PS exposure, $10^{6}$ platelets/ml were pre-treated with zVAD-FMK $(1 \mu \mathrm{M})$ for 10 minutes at $37^{\circ} \mathrm{C}$ in Tyrode buffer (pH 7.4) $2 \mathrm{mM} \mathrm{CaCl}_{2}$, washed once, stimulated with 10 and $15 \mu \mathrm{g} / \mathrm{ml}$ concentration of vancomycin at $37^{\circ} \mathrm{C}$ for 30 minutes and stained with Annexin V-FITC and active caspase-3 FITC antibody as mentioned before.

\section{Statistical analysis}

Data are provided as arithmetic means \pm SEM, statistical analysis was made by one-way ANOVA or Student's t-test, where applicable. Comparisons were made in absence or presence of vancomycin comparing blood from the same donors. Thus, where possible, paired t-test was performed.

\section{Results}

In order to determine the effect of vancomycin on platelet apoptosis, cell membrane phospholipid scrambling with subsequent exposure of phosphatidylserine at the cell surface was estimated from binding of fluorescent annexin V-Fluos. As revealed by confocal microscopy, a 30 minutes exposure to vancomycin resulted in annexin V-Fluos binding in human platelets (Fig. 1A), an effect reaching statistical significance at $\geq 1 \mu \mathrm{g} / \mathrm{ml}$ vancomycin when estimated with FACS analysis (Fig. 1B). The cell membrane scrambling was associated with decrease in platelet volumes, estimated from forward scatter in FACS (Fig 1C). In order to determine cell membrane integrity of the platelet cell membrane, lactate dehydrogenase (LDH) release was determined. As a result, the LDH concentration in the supernatant was similar following treatment with $10 \mu \mathrm{g}$ vancomycin/ml $(0.33 \pm 0.05 \mathrm{nM}, \mathrm{n}=3)$ as without treatment $(0.26 \pm 0.03 \mathrm{nM}, \mathrm{n}=3)$.

In search for the mechanism triggering cell membrane scrambling, the effect of vancomycin on cytosolic $\mathrm{Ca}^{2+}$ was determined utilizing Fluo-3AM fluorescence as an indicator of cytosolic $\mathrm{Ca}^{2+}$ activity. As illustrated in Fig. 2A and B, a 30 minutes exposure of human platelets to vancomycin tended to increase intracellular $\mathrm{Ca}^{2+}$ in platelets, an effect reaching statistical significance at $1 \mu \mathrm{g} / \mathrm{ml}$. Vancomycin-treated platelets also undergo mitochondrial depolarization (Fig. 2C). Vancomycin treatment was followed by ceramide 

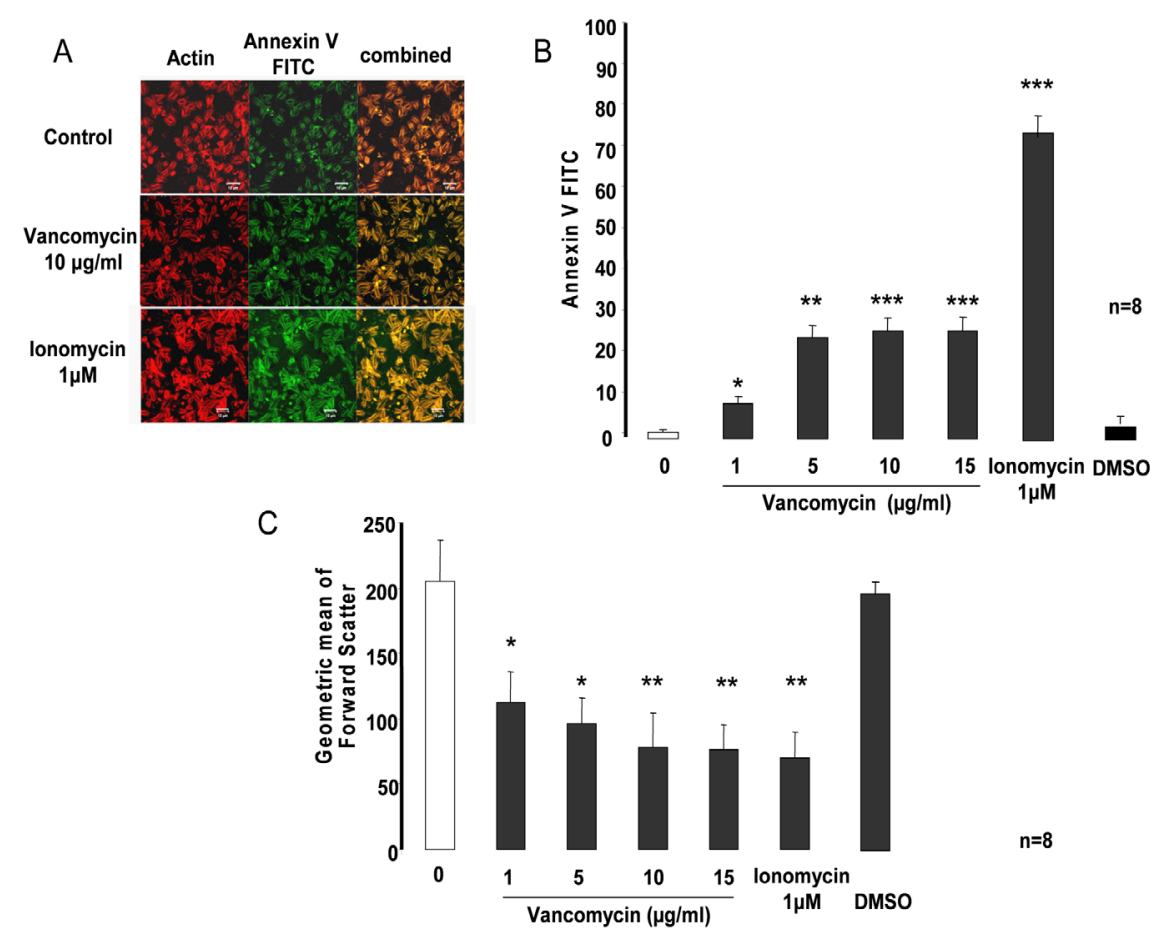

Fig. 1. Effect of vancomycin on phosphatidylserine exposure and forward scatter of human platelets. A. Representative immunofluorescence staining of annexin $\mathrm{V}$ in the absence (control) or presence of vancomycin $(10 \mu \mathrm{g} / \mathrm{ml})$. Red - rhodamine phalloidine, green - annexin V. Magnification bar represents $10 \mu \mathrm{m}$. Ionomycin $(1 \mu \mathrm{M})$ was used as a positive control. B. Arithmetic means \pm SEM $(n=8)$ of the percentage of human platelets binding Annexin V-Fluos following a 30 minutes exposure to Tyrode buffer 2 $\mathrm{mM} \mathrm{CaCl}_{2}$ (pH 7.4) in the absence (0) and presence of vancomycin $(1-15 \mu \mathrm{g} / \mathrm{ml}) .{ }^{*}(\mathrm{p}<0.05),{ }^{* *}(\mathrm{p}<0.01)$ and $* * *(\mathrm{p}<0.001)$ indicate statistically significant difference from respective value in the absence of vancomycin as determined by one-way ANOVA with Tukey's post-test for multiple comparison . Ionomycin $(1 \mu \mathrm{M})$ was used as a positive control and DMSO as the solvent control. C. Arithmetic means \pm SEM $(n=8)$ of the geometric mean of forward scatter of human platelets following a 30 minutes exposure to Tyrode buffer $2 \mathrm{mM} \mathrm{CaCl}_{2}$ in the absence (0) and presence of $1-15 \mu \mathrm{g} / \mathrm{ml}_{\text {vancomycin. }}^{*}(\mathrm{p}<0.05)$ and $* *(\mathrm{p}<0.01)$ indicate statistically significant difference from respective value in the absence of vancomycin as determined by one-way ANOVA with Tukey's post test for multiple comparison. Ionomycin $(1 \mu \mathrm{M})$ was used as a positive control and DMSO as the solvent control.

formation, an effect reaching statistical significance at $10 \mu \mathrm{g}$ vancomycin $/ \mathrm{ml}$ as revealed with FACS analysis (Fig. 2D).

In additional experiments, caspase- 3 activity was estimated utilizing FACS and immunofluorescence. As illustrated in Fig. 3A, a 30 minutes exposure to vancomycin was followed by an increase of caspase 3 activity, an effect reaching statistical significance at $\geq 1$ $\mu \mathrm{g} / \mathrm{ml}$ vancomycin (Fig 3B).

In order to test, whether the effect of vancomycin on cell membrane scrambling depended on caspase- 3 activity, platelets were exposed to vancomycin in the presence and absence of the pan-caspase inhibitor zVAD-FMK $(1 \mu \mathrm{M})$. As shown in Fig. 4A, zVAD-FMK did not significantly blunt the increase of annexin V-binding following vancomycin exposure. As shown in Fig. 4B, $1 \mu \mathrm{M}$ zVAD-FMK did significantly decrease caspase-3 activity following vancomycin treatment. Accordingly, the stimulation of PS exposure in platelets upon vancomycin treatment does not require caspase-3 activation. 
A

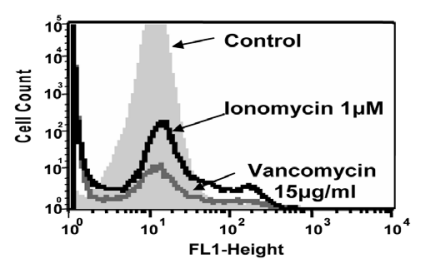

C

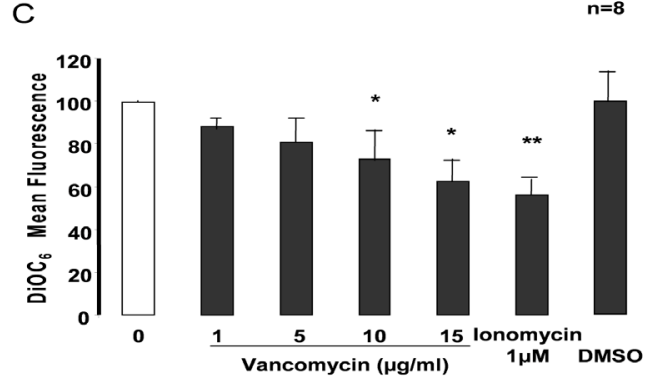

B

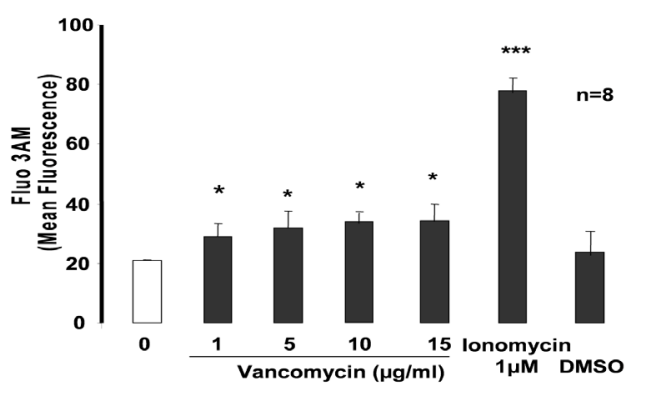

D

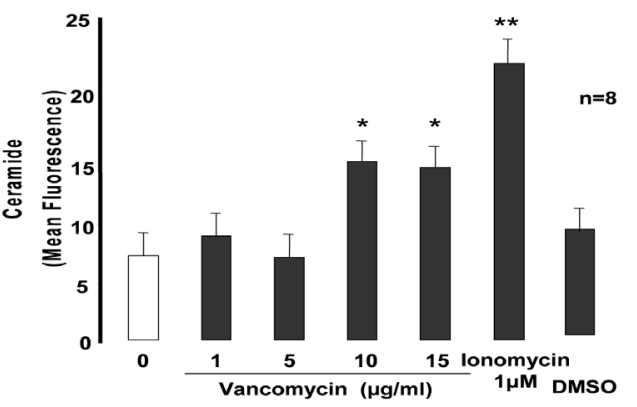

Fig. 2. Effect of vancomycin on cytosolic $\mathrm{Ca}^{2+}$ activity and ceramide formation in human platelets. A. Representative histogram of Fluo3 fluoresence following a 30 minutes exposure to Tyrode buffer $2 \mathrm{mM}$ $\mathrm{CaCl}_{2}$ in the absence (control, grey shadow) or presence $(15 \mu \mathrm{g} / \mathrm{ml}$ ) of vancomycin (Vanc, grey solid line) compared to $1 \mu \mathrm{M}$ ionomycin (black solid line). Ionomycin $(1 \mu \mathrm{M})$ was used as a positive control. B. Arithmetic mean \pm SEM $(n=8)$ of Fluo-3AM fluorescence in FACS analysis reflecting $\mathrm{Ca}^{2+}$ mobilisation of platelets following a 30 minutes exposure to Tyrode buffer $2 \mathrm{mM} \mathrm{CaCl}_{2}$ in the absence (control, open bar) and presence (closed bars) of vancomycin $(1-15 \mu \mathrm{g} / \mathrm{ml}) .^{*}(\mathrm{p}<0.05)$ and ${ }^{* * *}(\mathrm{p}<0.001)$ indicate statistically significant difference from respective value in the absence of vancomycin (one-way ANOVA). Ionomycin $(1 \mu \mathrm{M})$ was used as a positive control and DMSO as the solvent control. C. Arithmetic mean \pm SEM $(n=8)$ of DiOC 6 fluorescence in FACS analysis reflecting mitochondrial membrane potential of platelets following a 30 minutes exposure to platelet buffer in the absence (control) and presence of vancomycin (1-15 $\mu \mathrm{g} /$ $\mathrm{ml}) .{ }^{*}(\mathrm{p}<0.05)$ and ${ }^{* *}(\mathrm{p}<0.01)$ show significant decrease in mitochondrial membrane potential (one-way ANOVA). Ionomycin $(1 \mu \mathrm{M})$ was used as a positive control and DMSO as the solvent control. D. Arithmetic mean \pm SEM $(n=8)$ of IgG-FITC attached to ceramide monoclonal Ig in FACS analysis reflecting ceramide formation in platelets following a 60 minutes exposure to Tyrode buffer $2 \mathrm{mM} \mathrm{CaCl}{ }_{2}$ buffer in the absence (control, open bar) and presence (closed bars) of vancomycin $(1-15 \mu \mathrm{g} / \mathrm{ml}) .{ }^{*}(\mathrm{p}<0.05)$ and ${ }^{* *}(\mathrm{p}<0.01)$ show significant increase in ceramide formation (one-way ANOVA). Ionomycin $(1 \mu \mathrm{M})$ was used as a positive control and DMSO as the solvent control.

In order to explore the role of $\mathrm{Ca}^{2+}$ in the effect of vancomycin on cell membrane scrambling and caspase- 3 activation, platelets were exposed to vancomycin in the presence and absence ( $0.5 \mathrm{mM}$ EGTA) of extracellular $\mathrm{CaCl}_{2}$. As illustrated in Fig. $5 \mathrm{~A}$ and B, the removal of $\mathrm{Ca}^{2+}$ (and addition of $0.5 \mathrm{mM}$ EGTA) virtually abolished the effect of vancomycin $(10 \mu \mathrm{g} /$ $\mathrm{ml}$ ) on phosphatidylserine exposure and caspase-3 activation.

In an additional series, experiments were performed to test, whether thromboxane $B_{2}$ was released and CD62P (P-selectin) and activated integrin $\alpha_{11 b} \beta_{3}$ were expressed on the platelet membrane surface. As shown in Fig 6A, $10 \mu \mathrm{g}$ vancomycin/ml triggered the release of thromboxane $\mathrm{B}_{2}$, an effect not requiring the presence of extracellular $\mathrm{Ca}^{2+}$. As shown in Fig $6 \mathrm{~B}$ and $\mathrm{C}$, vancomycin $(1 \mu \mathrm{g} / \mathrm{ml})$ treatment was followed by significant upregulation of CD62P (P-selectin) and activated integrin $\alpha_{11 b} \beta_{3}$ activation at the platelet surface, an effect dependent on extracellular $\mathrm{Ca}^{2+}$. Vancomycin thus triggers apoptosis-like events paralleled by activation of platelets. Both apoptosis and activation were dependent on extracellular $\mathrm{Ca}^{2+}$. 


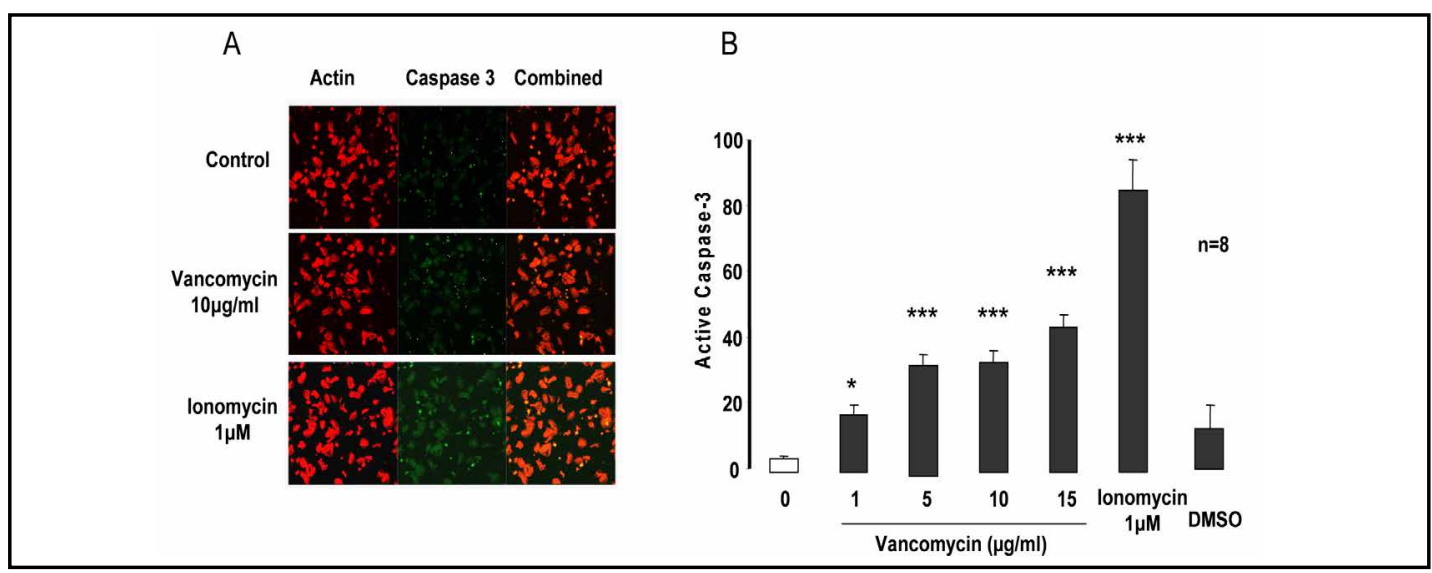

Fig. 3. Effect of vancomycin on caspase activity in human platelets. A. Representative immunofluorescence caspase-3 staining in the absence (control) or presence of vancomycin $(10 \mu \mathrm{g} / \mathrm{ml})$. Red - rhodamine phalloidine, green - caspase-3. Magnification bar represents $10 \mu \mathrm{m}$. Ionomycin $(1 \mu \mathrm{M})$ was used as a positive control. B. Arithmetic means \pm SEM $(n=8)$ of the $\%$ human platelets expressing active caspase- 3 following a 30 minutes exposure to Tyrode buffer $2 \mathrm{mM} \mathrm{CaCl}_{2}(\mathrm{pH} 7.4)$ in the absence (open bar) and presence (closed bars) of vancomycin $(1-15 \mu \mathrm{g} / \mathrm{ml}){ }^{*}(\mathrm{p}<0.05)$ and ${ }^{* * *}(\mathrm{p}<0.001)$ indicate statistically significant difference from respective value in the absence of vancomycin (one-way ANOVA). Ionomycin $(1 \mu \mathrm{M})$ was used as a positive control and DMSO as the solvent control.

Fig. 4. Influence of caspase inhibitor zVAD-FMK on vancomycin-induced phosphatidylserine exposure in human platelets. A. Arithmetic means \pm SEM (n $=5$ ) of the percentage of human platelets binding Annexin V-Fluos following a 30 minutes exposure to Tyrode buffer $2 \mathrm{mM} \mathrm{CaCl}_{2}(\mathrm{pH} 7.4)$ in the absence $(0$, white bar) and presence of vancomycin (10-15 $\mu \mathrm{g} / \mathrm{ml}$ ) in the absence (dark grey bars) and presence (light grey bars) of $1 \mu \mathrm{M}$ zVAD-FMK. ${ }^{* *}(\mathrm{p}<0.01)$ and $* * * \quad(\mathrm{p}<0.001)$ indicate statistically significant difference from respective value in the absence of vancomycin (Student's paired t-test). Ionomycin (1 $\mu \mathrm{M}$ ) was used as a positive control. B. Arithmetic means \pm SEM $(n=5)$ of the percentage of human platelets with active caspase-3 following a 30 minutes exposure to Tyrode buffer $2 \mathrm{mM} \mathrm{CaCl}_{2}(\mathrm{pH}$ $7.4)$ in the absence ( 0 , white bar) and presence of $10 \mu \mathrm{g} / \mathrm{ml}$ vancomycin in the absence (dark grey bars) and presence (light grey bars) of $1 \mu \mathrm{M}$ zVADFMK. $^{* * *}(\mathrm{p}<0.001)$ indicates statistically significant difference to respective value in the absence of vancomycin (one way ANOVA). \#\#\# (p<0.001)

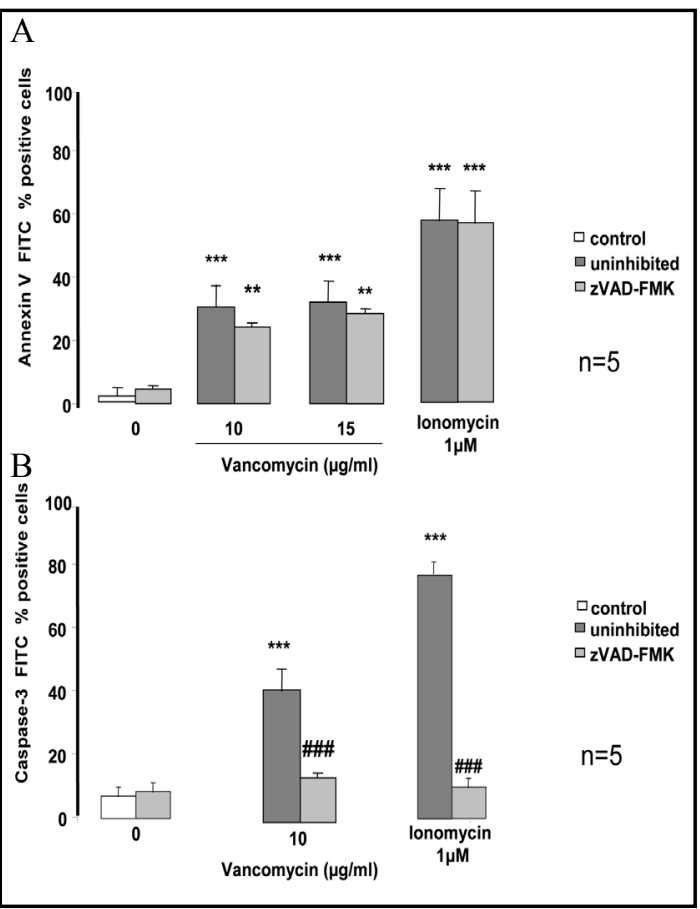
indicates statistically significant difference from respective value in the absence of zVAD-FMK (Student's paired t-test). Ionomycin $(1 \mu \mathrm{M})$ was used as a positive control.

\section{Discussion}

The present observations reveal a novel effect of vancomycin, i.e. the stimulation of platelet activation and apoptosis. The concentration required for this effect is achieved during antibiotic treatment [20-28]. Vancomycin treatment may be required from 10 up to 28 days [29]. Vancomycin has previously been shown to inhibit platelet aggregation [30-34]. 
Fig. 5. Effect of $\mathrm{Ca}^{2+}$ removal on vancomycin induced annexin V-binding in human platelets. A. Arithmetic means \pm SEM $(n=6)$ of the percentage of human platelets binding Annexin V-Fluos following 30 minutes treatment with vancomycin in the presence (black bar) and nominal absence (grey bar) of extracellular $\mathrm{Ca}^{2+}$. \#\# $(\mathrm{p}<0.01)$ and \#\# $(\mathrm{p}<0.001)$ indicate statistically significant difference from respective value in the presence of calcium (paired t-test). ${ }^{* * *}(\mathrm{p}<0.001)$ indicates significant difference from non-stimulated control (Student's paired t-test). Ionomycin $(1 \mu \mathrm{M})$ was used as a positive control. B. Arithmetic means \pm SEM $(n=5)$ of the percentage of human platelets with activated caspase- 3 following a 30 minutes treatment with vancomycin in the presence (black bar) and absence (grey bar) of extracellular $\mathrm{Ca}^{2+}$. *** $(\mathrm{p}<0.001)$ indicates statistically significant difference from non-stimulated corresponding control (one-way ANOVA) and \#\#\# (p<0.001) indicates statistically significant difference from respective value in the presence of calcium (Student's paired t-test). Ionomycin $(1 \mu \mathrm{M})$ was used as a positive control.

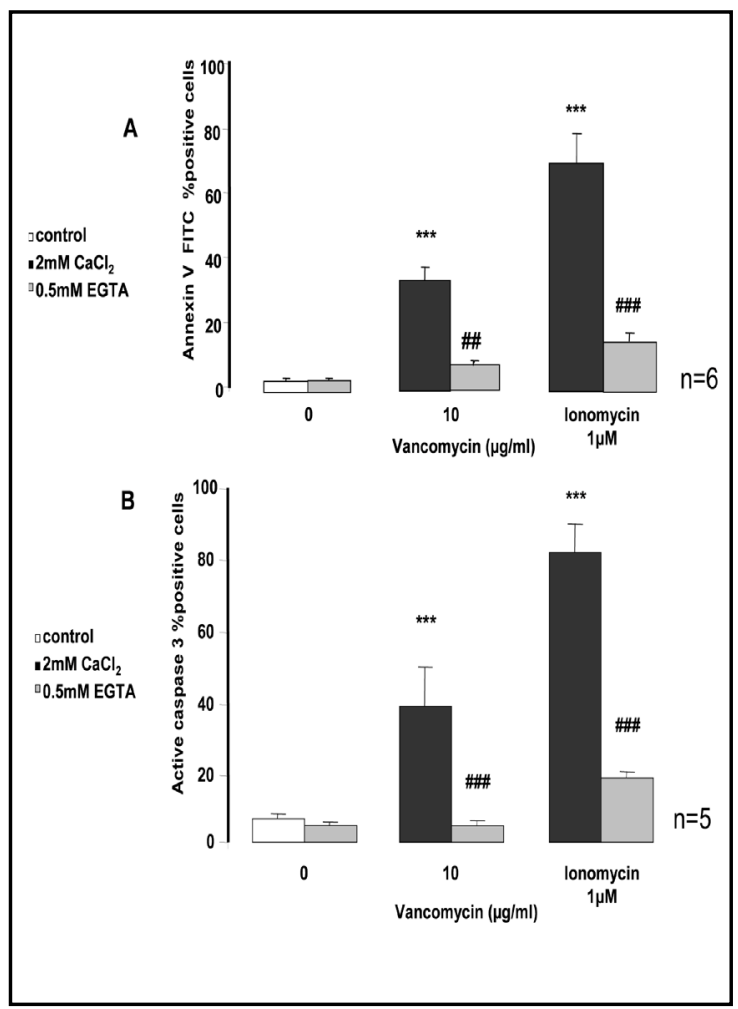

To the best of our knowledge, an effect of vancomycin on platelet activation and apoptosis or thrombosis has never been reported. Vancomycin did not significantly increase lactate dehydrogenase $(\mathrm{LDH})$ release, indicating that vancomycin did not affect cell membrane integrity.

The vancomycin-induced apoptosis is paralleled by depolarization of the mitochondria, activation of caspase- 3 and scrambling of the cell membrane. The vancomycin induced platelet apoptosis and activation are virtually abolished in the absence of extracellular $\mathrm{Ca}^{2+}$. Thus, the presence of $\mathrm{Ca}^{2+}$ is apparently a prerequisite for the stimulation of cell membrane scrambling. Further experiments were performed to elucidate whether vancomycin triggers the formation of ceramide, which has previously been shown to sensitize erythrocytes to the scrambling effect of cytosolic $\mathrm{Ca}^{2+}[35,36]$. As a matter of fact, the exposure of platelets to vancomycin was indeed followed by significant ceramide formation. Stimulation of platelets leads to release of $\mathrm{Ca}^{2+}$ from intracellular stores and subsequent activation of calpain [37] which in turn modifies several substrates in platelets and triggers platelet activation, migration, apoptosis and adhesion [38].

$\mathrm{Ca}^{2+}$ influx into platelets is regulated by SGK-1 and NF- $\kappa \mathrm{B}$ [39]. Removal of extracellular $\mathrm{Ca}^{2+}$ blunted the upregulation of CD62P (P-selectin) and activated integrin $\alpha_{\mathrm{IIb}} \beta_{3}$, an effect possibly again involving calpain. $\mathrm{Ca}^{2+}$-independent thromboxane $\mathrm{B}_{2}$ release may be due to $\mathrm{Ca}^{2+}$-independent phospholipase $\mathrm{A}_{2}$ accomplishing $\mathrm{Ca}^{2+}$-independent arachidonic acid release from platelets $[40,41]$. Thromboxane $B_{2}$ is a stable hydrolysis product of the bioactive but unstable thromboxane $A_{2}$. Thromboxane is involved in vascular permeability and inflammation [42].

Somewhat surprisingly, the vancomycin-induced platelet apoptosis was not abrogated by the pan-caspase inhibitor zVAD-FMK. Apparently, $\mathrm{Ca}^{2+}$ and ceramide trigger cell membrane scrambling at least in part by mechanisms other than caspase-3 activation. According to earlier studies [43], caspase-independent but $\mathrm{Ca}^{2+}$-dependent phosphatidylserine exposure in platelets is more typical of agonist-mediated activation-associated events resembling apoptosis [44]. Use of ionomycin as a positive control shows that the effect of vancomycin on platelets is similar to that of a calcium ionophore. Other than activation of platelets by 


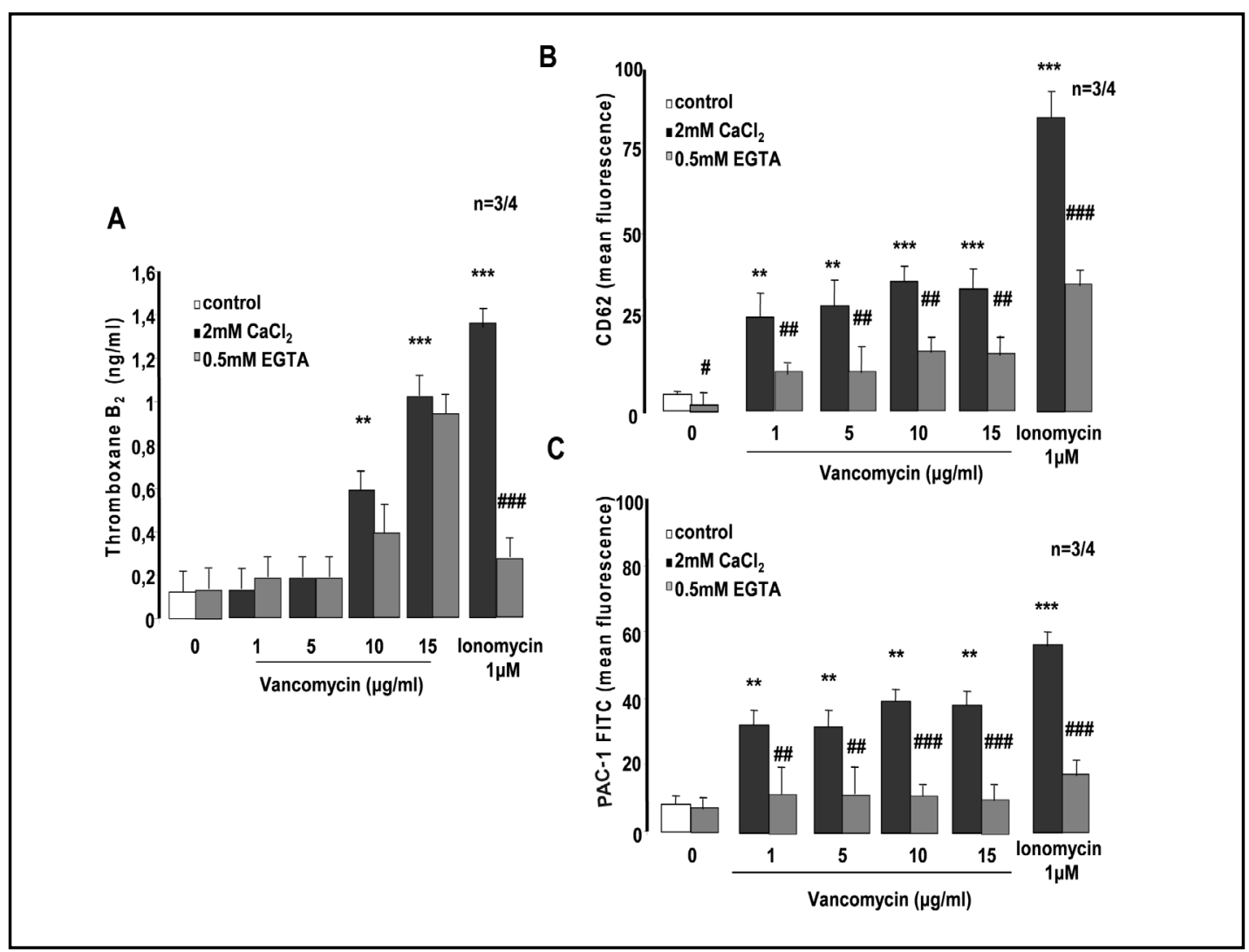

Fig. 6. Activation of platelet function by vancomycin. A. Arithmetic mean \pm SEM $(n=3-4)$ of thromboxane $B_{2}$ secretion from platelets after 30 minutes of vancomycin treatment compared to negative control (white bar) and positive control (ionomycin $1 \mu \mathrm{M}){ }^{* *}(\mathrm{p}<0.01)$ and ${ }^{* * *}(\mathrm{p}<0.001)$ indicate statistically significant difference from negative control by one-way ANOVA and \#\#\# $(\mathrm{p}<0.001)$ indicates statistically significant difference from respective value in the presence of calcium (Student's paired t-test). Ionomycin $(1 \mu \mathrm{M})$ was used as a positive control. B. Arithmetic mean \pm SEM ( $n=3-4)$ of \% CD62P (P selectin) positive platelets after 30 minutes of vancomycin treatment compared to negative control (white bar) and positive control (ionomycin $1 \mu \mathrm{M}){ }^{* *}(\mathrm{p}<0.01)$ and ${ }^{* * *}(\mathrm{p}<0.001)$ indicate statistically significant difference from negative control by one-way ANOVA and \#\# $(\mathrm{p}<0.01)$ and \#\#\# $(\mathrm{p}<0.001)$ indicate statistically significant difference to value in the presence of calcium (Student's paired t-test). Ionomycin $(1 \mu \mathrm{M})$ was used as a positive control. C. Arithmetic mean \pm SEM $(n=3-4)$ of $\%$ integrin $\alpha_{\mathrm{IIb}} \beta_{3}$ positive platelets after 30 minutes of vancomycin treatment compared to negative control (white bar) and positive control (ionomycin $1 \mu \mathrm{M})$. ${ }^{* *}(\mathrm{p}<0.01)$ and ${ }^{* * *}(\mathrm{p}<0.001)$ indicate statistically significant difference from negative control by one-way ANOVA, \#\# $(\mathrm{p}<0.01)$ and \#\#\# ( $<<0.001)$ indicate statistically significant difference from respective value in the presence of calcium (Student's paired t-test). Ionomycin $(1 \mu \mathrm{M})$ was used as a positive control.

the agonists thrombin or collagen-related peptide (CRP) the stimulation of platelets by the $\mathrm{Ca}^{2+}$-ionophore ionomycin is limited to $\mathrm{Ca}^{2+}$ entry and subsequent triggering of $\mathrm{Ca}^{2+}$ sensitive platelet functions [37].

Phosphatidylserine exposing apoptotic platelets are expected to be engulfed by phagocytosing cells and thus to disappear from circulating blood. Excessive apoptosis is thus expected to result in thrombocytopenia. The thrombocytopenia following treatment with vancomycin may, however, largely result from immune reactions [2-4]. On the other hand, vancomycin causes thrombocytopenia even in the absence of drug-dependent antibodies [45]. Thus, at least in theory, the influence of vancomycin on platelet number may in part reflect a direct effect of vancomycin on platelets. 
In conclusion, vancomycin treatment of human blood platelets triggered ceramide formation, caspase- 3 activation, cell shrinkage and cell membrane scrambling. The cell membrane scrambling required the presence of $\mathrm{Ca}^{2+}$. Vancomycin-induced cell membrane scrambling presumably accelerates the clearance of platelets from circulating blood .

\section{Acknowledgements}

The authors acknowledge the meticulous preparation of the manuscript by Lejla Subasic. This study was supported by the Deutsche Forschungsgemeinschaft (KFO 274 and SFB766).

\section{References}

1 Vandecasteele SJ, De Vriese AS: Recent changes in vancomycin use in renal failure. Kidney Int 2010;77:760764.

2 Anand A, Chauhan HK: Piperacillin and vancomycin induced severe thrombocytopenia in a hopsitalized patient. Platelets 2011;22:294-301.

-3 Kenney B, Tormey CA: Acute vancomycin-dependent immune thrombocytopenia as an anamnestic response. Platelets 2008;19:379-383.

-4 Nasraway SA, Shorr AF, Kuter DJ, O'Grady N, Le VH, Cammarata SK: Linezolid does not increase the risk of thrombocytopenia in patients with nosocomial pneumonia: comparative analysis of linezolid and vancomycin use. Clin Infect Dis 2003;37:1609-1616.

5 Christie DJ, van Buren N, Lennon SS, Putnam JL: Vancomycin-dependent antibodies associated with thrombocytopenia and refractoriness to platelet transfusion in patients with leukemia. Blood 1990;75:518523.

6 Mizon P, Kiefel V, Mannessier L, Mueller-Eckhardt C, Goudemand J: Thrombocytopenia induced by vancomycin-dependent platelet antibody. Vox Sang 1997;73:49-51.

7 Okamoto H: Vancomycin-induced immune thrombocytopenia. N Engl J Med 2007;356:2537-2538. Von Drygalski A, Curtis BR, Bougie DW, McFarland JG, Ahl S, Limbu I, Baker KR, Aster RH: Vancomycininduced immune thrombocytopenia. N Engl J Med 2007;356:904-910.

-9 Kile BT: The role of the intrinsic apoptosis pathway in platelet life and death. J Thromb Haemost 2009;7 Suppl 1:214-217.

10 Akinnusi ME, Hattemer A, Gao W, El Solh AA: Does linezolid modulate lung innate immunity in a murine model of methicillin-resistant Staphylococcus aureus pneumonia? Crit Care Med 2011;39:1944-1952.

11 Leytin V, Allen DJ, Mykhaylov S, Lyubimov E, Freedman J: Thrombin-triggered platelet apoptosis. J Thromb Haemost 2006;4:2656-2663.

12 Towhid ST, Schmidt EM, Schmid E, Munzer P, Qadri SM, Borst O, Lang F: Thymoquinone-induced platelet apoptosis. J Cell Biochem 2011;112:3112-3121.

13 Zhang W, Liu J, Sun R, Zhao L, Du J, Ruan C, Dai K: Calpain activator dibucaine induces platelet apoptosis. Int J Mol Sci 2011;12:2125-2137.

14 Varga-Szabo D, Braun A, Nieswandt B: STIM and Orai in platelet function. Cell Calcium 2011;50:270-278.

15 del Conde I, Cruz MA, Zhang H, Lopez JA, Afshar-Kharghan V: Platelet activation leads to activation and propagation of the complement system. J Exp Med 2005;201:871-879.

16 Smyth SS, McEver RP, Weyrich AS, Morrell CN, Hoffman MR, Arepally GM, French PA, Dauerman HL, Becker RC: Platelet functions beyond hemostasis. J Thromb Haemost 2009;7:1759-1766.

17 Prevost N, Woulfe D, Tognolini M, Brass LF: Contact-dependent signaling during the late events of platelet activation. J Thromb Haemost 2003;1:1613-1627.

18 Wonerow P, Pearce AC, Vaux DJ, Watson SP: A critical role for phospholipase Cgamma2 in alphallbbeta3mediated platelet spreading. J Biol Chem 2003;278:37520-37529.

19 Kulkarni S, Woollard KJ, Thomas S, Oxley D, Jackson SP: Conversion of platelets from a proaggregatory to a proinflammatory adhesive phenotype: role of PAF in spatially regulating neutrophil adhesion and spreading. Blood 2007;110:1879-1886.

20 American Thoracic Society, Infectious Diseases Society of America: Guidelines for the management of adults with hospital-acquired, ventilator-associated, and healthcare-associated pneumonia. Am J Respir Crit Care Med 2005;171:377-416.

-21 Bastani B, Minton J, Islam S: Insufficient penetration of systemic vancomycin into the PermCath lumen. Nephrol Dial Transplant 2000;15:1035-1037. 
22 Giuliano C, Haase KK, Hall R: Use of vancomycin pharmacokinetic-pharmacodynamic properties in the treatment of MRSA infections. Expert Rev Anti Infect Ther 2010;8:95-106.

23 Hidayat LK, Hsu DI, Quist R, Shriner KA, Wong-Beringer A: High-dose vancomycin therapy for methicillinresistant Staphylococcus aureus infections: efficacy and toxicity. Arch Intern Med 2006;166:2138-2144.

24 Lodise TP, Miller CD, Graves J, Evans A, Graffunder E, Helmecke M, Stellrecht K: Predictors of high vancomycin MIC values among patients with methicillin-resistant Staphylococcus aureus bacteraemia. J Antimicrob Chemother 2008;62:1138-1141.

25 Lodise TP, Graves J, Evans A, Graffunder E, Helmecke M, Lomaestro BM, Stellrecht K: Relationship between vancomycin MIC and failure among patients with methicillin-resistant Staphylococcus aureus bacteremia treated with vancomycin. Antimicrob Agents Chemother 2008;52:3315-3320.

26 Sakoulas G, Moise-Broder PA, Schentag J, Forrest A, Moellering RC Jr, Eliopoulos GM: Relationship of MIC and bactericidal activity to efficacy of vancomycin for treatment of methicillin-resistant Staphylococcus aureus bacteremia. J Clin Microbiol 2004;42:2398-2402.

27 Soriano A, Marco F, Martinez JA, Pisos E, Almela M, Dimova VP, Alamo D, Ortega M, Lopez J, Mensa J: Influence of vancomycin minimum inhibitory concentration on the treatment of methicillin-resistant Staphylococcus aureus bacteremia. Clin Infect Dis 2008;46:193-200.

-28 Tenover FC, Moellering RC Jr: The rationale for revising the Clinical and Laboratory Standards Institute vancomycin minimal inhibitory concentration interpretive criteria for Staphylococcus aureus. Clin Infect Dis 2007;44:1208-1215.

29 Young LS: Hematologic effects of linezolid versus vancomycin. Clin Infect Dis 2004;38:1065-1066.

30 Baugh RF, Jacoby C, Brown JE, Hougie C: Effect of vancomycin on ristocetin and bovine PAF-induced agglutination of human platelets. Thromb Res 1978;12:511-521.

-31 Coller BS, Lundberg WB, Gralnick HR: Effects of vancomycin on platelets, plasma proteins and hepatitis B surface antigen. Thromb Diath Haemorrh 1975;34:83-93.

32 Coller BS, Gralnick HR: Studies on the mechanism of ristocetin-induced platelet agglutination. Effects of structural modification of ristocetin and vancomycin. J Clin Invest 1977;60:302-312.

-33 Coller BS: Polybrene-induced platelet agglutination and reduction in electrophoretic mobility: enhancement by von Willebrand factor and inhibition by vancomycin. Blood 1980;55:276-281.

34 Moake JL, Cimo PL, Peterson DM, Roper P, Natelson EA: Inhibition of ristocetin-induced platelet agglutination by vancomycin. Blood 1977;50:397-406.

35 Lang F, Gulbins E, Lang PA, Zappulla D, Foller M: Ceramide in suicidal death of erythrocytes. Cell Physiol Biochem 2010;26:21-28.

-36 Lang KS, Myssina S, Brand V, Sandu C, Lang PA, Berchtold S, Huber SM, Lang F, Wieder T: Involvement of ceramide in hyperosmotic shock-induced death of erythrocytes. Cell Death Differ 2004;11:231-243.

-37 Wolf BB, Goldstein JC, Stennicke HR, Beere H, Amarante-Mendes GP, Salvesen GS, Green DR: Calpain functions in a caspase-independent manner to promote apoptosis-like events during platelet activation. Blood 1999;94:1683-1692.

-38 Randriamboavonjy V, Fleming I: All cut up! The consequences of calpain activation on platelet function. Vascul Pharmacol 2012;56:210-215.

-39 Towhid ST, Nega M, Schmidt EM, Schmid E, Albrecht T, Münzer P, Borst O, Gawaz M, Götz F, Lang F: Stimulation of platelet apoptosis by peptidoglycan from Staphylococcus aureus 113. Apoptosis 2012;17:998-1008.

40 Hoffmann M, Lopez JJ, Pergola C, Feisst C, Pawelczik S, Jakobsson PJ, Sorg BL, Glaubitz C, Steinhilber D, Werz O: Hyperforin induces $\mathrm{Ca}^{2+}$-independent arachidonic acid release in human platelets by facilitating cytosolic phospholipase $\mathrm{A}_{2}$ activation through select phospholipid interactions. Biochim Biophys Acta 2010;1801:462-472.

41 Poeckel D, Tausch L, Kather N, Jauch J, Werz O: Boswellic acids stimulate arachidonic acid release and 12-lipoxygenase activity in human platelets independent of $\mathrm{Ca}^{2+}$ and differentially interact with platelettype 12-lipoxygenase. Mol Pharmacol 2006;70:1071-1078.

42 Bogatcheva NV, Sergeeva MG, Dudek SM, Verin AD: Arachidonic acid cascade in endothelial pathobiology. Microvasc Res 2005;69:107-127.

43 Borst O, Schmidt EM, Munzer P, Schonberger T, Towhid ST, Elvers M, Leibrock C, Schmid E, Eylenstein A, Kuhl D, May AE, Gawaz M, Lang F: The serum- and glucocorticoid-inducible kinase 1 (SGK1) influences platelet calcium signaling and function by regulation of Orai1 expression in megakaryocytes. Blood 2012;119:251-261.

44 Schoenwaelder SM, Yuan Y, Josefsson EC, White MJ, Yao Y, Mason KD, O'Reilly LA, Henley KJ, Ono A, Hsiao S, Willcox A, Roberts AW, Huang DC, Salem HH, Kile BT, Jackson SP: Two distinct pathways regulate platelet phosphatidylserine exposure and procoagulant function. Blood 2009;114:663-666.

45 Ruggero MA, Abdelghany 0, Topal JE: Vancomycin-induced thrombocytopenia without isolation of a drugdependent antibody. Pharmacotherapy 2012;32:e321-e325. 